\title{
Vitamin B6 and Vitamin B1 Status in Acute Psychosis
}

\author{
Jos Utama*, Hera G. Tamara**, Drupadi Dillon***, Evi Setiadi ****, Wilmar Musram ****
}

\begin{abstract}
Abstrak
Pada pertengahan abad ke-20 konsep biopsikiatri sebagai dasar penyakit jiwa mulai dikembangkan. Telah ditemukan beberapa zat kimia seperti LSD (lysergic acid diethylamide) dan reserpin yang dapat menimbulkan gejala-gejala psikosis. Ternyata bahwa LSD dan serotonin (5HT) mempunyai struktur yang serupa, sedangkan hasil penguraian serotonin mempunyai sifat halusinogenik yang ampuh. Diketahui pula bahwa sintesis serotonin dan norepinefrin (NE) mutlak memerlukan piridoksalfosfat (PLP), bentuk aktif vitamin B6, sebagai kofaktor. Hingga sekarang kepastian mengenai perubahan $5 H T$ dan NE pada penderita psikosis masih belum dapat disimpulkan. Tujuan penelitian kami ialah untuk mengetahui perubahan status vitamin B6 dan vitamin BI penderita dengan berbagai tingkat kegawatan keadaan psikosis. Hasil sementara menunjukkan bahwa status vitamin B6 langsung berhubungan dengan keadaan psikosis sedangkan status vitamin BI tidak.
\end{abstract}

\begin{abstract}
In the midst of our century, the biological concept of the pathogenesis of mental illness was launched. Several agents were discovered that mimic the symptoms of mental disease like LSD (lysergic acid diethylamide) and reserpine. It was found that LSD and serotonin (5HT) were structurally similar and that the breakdown products of SHT had potent hallucinogenic properties. It was also known that the synthesis of $5 H T$ and norepinephrine (NE) were pyridoxalphosphate (PLP), the active form of vitamin B6, dependent. However, definitive findings concerning the $5 H T$ and NE alterations in psychotics are at present still inconclusive. The goal of our study is to look for changes between the vitamin B6 and vitamin B1 status of the patients and the different stages of psychosis. Preliminary findings show that vitamin B6 status in psychotic patients is phase dependent while vitamin BI status is not.
\end{abstract}

Key words : acute psychosis, serotonin, norepinephrine, vitamin B6 and vitamin B1 status.

\section{INTRODUCTION}

In the midst of our century, several relatively effective and selective drugs for the management of schizophrenia and manic-depressive patients were introduced. This condition stimulated the biological concept of the pathogenesis of mental illness. In addition, other agents were discovered that mimic some of the symptoms of mental illnesses. These include lysergic acid diethylamide (LSD) which induces hallucinations and altered emotional states and antihypertensive agents, such as reserpine, which can cause depression. At the same time, it was noted that serotonin (5hydroxytryptamine, 5HT) and LSD were structurally similar and that breakdown products of 5HT, such as dimethyltryptamine, had potent hallucinogenic properties. "These observations led to speculations that a deficiency of amine neurotransmitters (NT) in the central nervous system (CNS) might be causative of depression or that an excess could result in mania. Further, since antipsychotic agents antagonize the actions of dopamine (DA) as a NT in the forebrain, it was

\footnotetext{
"Department of Neurology: "** Department of Nutrition, ${ }^{* * *}$ Department of Biochemistry, Faculty of Medicine, University of Indonesia, Jakarta, Indonesia. "* Mental State Hospital Bogor, West Java, Indonesia.
} 
proposed that there may be a state of functional overactivity of DA in the limbic system or cerebral cortex in schizophrenia or mania.

Until the mid 1960s the only known NTs were a handful of biogenic amines. In the late 1960s the role of amino acids, such as gamma aminobutyric acid (GABA), glycine and glutamate, as NTs became apparent. The decade of 1960 witnessed the appreciation of peptides as NTs. Although peptides represent the most diverse group of transmitters, yet the amino acids are the most abundant NTs. GABA, the most inhibitory NT, accounts for $25-40 \%$ of synapses, depending on the brain region.

During early development, a rapid and massive death occurs among the postmitotic neurons whose axons have reached and connected with their target territory. ${ }^{2,3}$ The ability of neurons to survive through this developmental death period has been hypothesized to depend on target-derived neuronotrophic factors, which taken up by the axonal terminals and used to stimulate life supporting cell activities. The concept of a nerve growth factor (NGF) was born, and in the 1960 s its existence and general properties were established by Levy-Montalcini et al. ${ }^{4,5}$ The discovery of NGF has been a milestone in modern neurobiology. We know now that NGF is critical for the survival of certain neurons as well as for the outgrowth of their neurites and that it also stimulates the synthesis of transmitter producing enzymes. Glial cells surround and greatly outnumber - neurons in both the peripheral nervous system (PNS) - (satellite and Schwann cells) and the CNS (astroglia, oligodendroglia and microglia). Certain roles of glial cells have long been recognized eg, electrical insulation (myelin), histological organization (radial glia, glial lining) and monitoring of extracellular fluid composition (blood -brain -barrier). The discovery of very close anabolic and metabolic interrelations prompted Hyden et al, ${ }^{6}$ to propose the concept of a glia-neuron functional unit.

Further analyses have revealed the ability of glial cells to produce and release neuronotrophic agents, like pyruvate, and their ability to respond to neuronal signals. ${ }^{7,8}$ It is also known, that the $\mathrm{B}$ vitamins especially the vitamins $\mathrm{B} 1, \mathrm{~B} 6, \mathrm{~B} 12$ and folic acid are essential cofactors for the normal activities of cell neurons and their axons, including regenerative processes. A deficiency of vitamin B complex may result in disturbances of function of both the PNS (nerve conduction velocity) and CNS (higher cortical functions) as well as the synthesis of NTs like serotonin and GABA.

In spite of much work, definitive findings concerning the 5HT and NE alterations in psychotics are at present still inconclusive. The key problem has been the absence of good methods for examining localized NT and functional changes. However, as the synthesis of $5 \mathrm{HT}$ and $\mathrm{NE}$ is vitamin $\mathrm{B} 6$ dependent, estimation of vitamin B6 and vitamin B1 status in the diverse stages of psychosis could provide us more information. We hypothetize that, metabolic and nutrient requirements in acute psychotics will be higher than under normal conditions, consequently vitamin B6 and vitamin B1 status will fluctuate according to the acuteness of the illness. The objective of this study is to look for alterations between the vitamin B6 and vitamin B1 status and the stage of psychosis of the patients.

\section{METHODS}

The material consisted of 27 acute psychotic patients, 16 males and 11 females, ages between 17-60 years. All cases were new inpatients, admitted for at least one month in the State Mental Hospital of Bogor, West Java, with pure mental illnesses. The examination consisted of general physical diagnostics, clinical neurological and mental assessment, routine blood and vitamin B6 and vitamin B1 status. The examinations had been done twice, prior to the treatment, directly at the time of admittance and secondly, after one month of hospital treatment. Standard psychotic medications were chlorpromazine, diazepam, carbamazepine parenterally and orally, besides phenobarbital and trihexyphenydil tablets for epileptic insults and parkinsonism.

The vitamin B1 status was expressed in the thiamine-pyrophosphate (TPP) effect which is determined by the method of Schouten, a modification of the Dreyfus test. ${ }^{9}$

Vitamin B6 status is determined by the erythrocyte aminotransferase (EAT) activity test and expressed in the coefficient of EAT activation (CA) ${ }^{10)}$.

In previous studies a TPP effect $<27 \%$ and a CA $<1.40$ were found for a normal vitamin B1 and vitamin B6 status, respectively. ${ }^{9,10}$ The TPP value greater than $27 \%$ and that of $\mathrm{CA}$ greater than 1.40 indicate the deficiency in vitamin $\mathrm{B} 1$ and $\mathrm{B} 6$ respectively. The t-test was used to compare the TPP and CA values before and after treatment.

\section{RESULTS}

The physical and mental condition of the patients prior to treatment were as follows: 11 patients $(40.7 \%)$ were underweight and another $40.7 \%$ had a low $\mathrm{Hb}$ content. 
Psychiatric assessment revealed schizophrenia and related psychoses including one epileptic and three undifferentiated cases, all were in an acute anxiety state.

After one month of hospitalization 9 patients (33.3\%) were still underweight and 5 patients $(18.5 \%)$ remained slightly anemic, while the acute psychotic state changed into a quiet cooperative behaviour. Biochemical values, like glucose and liver functions were normal before and after treatment.

Prior to treatment, 15 patients $(55.6 \%)$ showed a low vitamin B1 status (TPP effect $27 \%$ ) and 16 patients (59.3\%) a low vitamin B6 status (CA 1.40), however a combined low vitamin $\mathrm{B} 1$ and vitamin $\mathrm{B} 6$ status was seen in 21 patients (77.8\%) (Figure 1). A second evaluation of the same patients, one month later, revealed a normal vitamin B6 status for all but one patient (3.7\%) (Figure 2), with a slight improvement of the vitamin B1 status for 2 patients (7.4\%) (Figure 3). Comparing the vitamin B6 status of the patients on admittance $(C A=1.49 \pm 0.18)(x \pm S D)$ and after one month of treatment $(C A=1.29 \pm 0.09)(x \pm$ $\mathrm{SD})$, the difference is extremely significant ( $\mathrm{p}<$ 0.0005 ). In contrast to the vitamin $\mathrm{B} 1$ status of the patients prior to treatment (\% TPP effect $=37.11 \pm$ $31.07)(\mathrm{x} \pm \mathrm{SD})$ and after one month of treatment (\% TPP effect $=25.935 \pm 11.72)(x \pm S D)$, the difference is just significant $(0.025<\mathrm{p}<0.05)$.

\section{DISCUSSION}

It is well known that the $\mathrm{B}$ complex vitamins are essential for the normal function of the central and peripheral nervous system. Although each member of the B complex vitamins has a specific role in metabolism, yet as a group they are all vital for the maintenance, the normal function and the regeneration of the nervous system. The recommended dietary allowances (RDA) for vitamins to ensure health are periodically revised by the Dietary Allowances Committee of the Food and Nutrition Board. These allowances are set at levels sufficiently high to cover the needs of almost all healthy individuals in their age and sex category. Levels are set high because the exact amount of vitamins needed by each individual is not known, and estimations are made from experiments on a limited scale. If the upper limit of this range is taken as the recommended allowance, it is unlikely that a deficiency will occur. Those with intakes below the recommended allowance, will not necessarily develop a deficiency, but the risk of becoming deficient increases if the intake is less than the amount recommended.
Increased tissue requirements for ritamins may cause a nutritional deficiency to develop, despite the ingestion of a diet that had previously been adequate. For example, requirements for some vitamins may be altered by the use of certain antivitamin drugs, such as the interference with the utilization of folic acid by trimethoprim. ${ }^{11}$ Diseases associated with an increased metabolic rate, such as hyperthyroidism and conditions accompanied by fever or tissue wasting, also increase the bodys requirements for vitamins. The impact of disease on requirements for nutrients may vary according to its phase and intensity. The need for therapy with vitamins may change throughout the course of the illness and eventually, cure should be associated with a tapering down of the vitamin therapy.

The induction of convulsive seizures by pyridoxine deficiency may be the result of a lowered concentration of GABA. Glutamate decarboxylase, a pyridoxal phosphate requiring enzyme, catalyses the synthesis of this inhibitory CNS neurotransmitter. In addition, pyridoxine deficiency leads to decreased concentrations of the neurotransmitters NE and serotonin. ${ }^{12}$ The dramatic improvement of the vitamin B6 status, the rapid shifting from a deficient state to an almost normal condition, indicates a direct connection between the vitamin B6 status of the patients and the course of the disease.

As PLP is an essential cofactor for the synthesis of serotonin and NE, a fluctuation in the vitamin B6 status may result in similar changes in serotonin and NE levels. An increase or decrease in the serotonin and NE levels of psychotic patients is dependent both upon the vitamin B6 status and the phase and intensity of the mental process. An acute psychotic patient requires a higher amount of nutrients and subsequently will have a low vitamin B6 status, resulting in lower levels of serotonin and NE. On the other hand, chronic and stable psychotics will require less nutrients.

Thus an adequate vitamin B6 status together with an average normal diet will produce normal to high normal serotonin and NE levels in these patients. Although some preliminary findings are supporting these conclusions, yet because of the limited material, an evaluation of more patients over a longer period of time together with a more extensive study would be the answer.

We conclude that the vitamin B6 status of the patients is fluctuating paradoxically to the stage of psychosis. The higher the state of mental disintegration the lower the vitamin B6 status of the patients.

No dramatic change is found in the vitamin B1 status of the acute psychotic patients before treatment and after one month of hospitalization. 


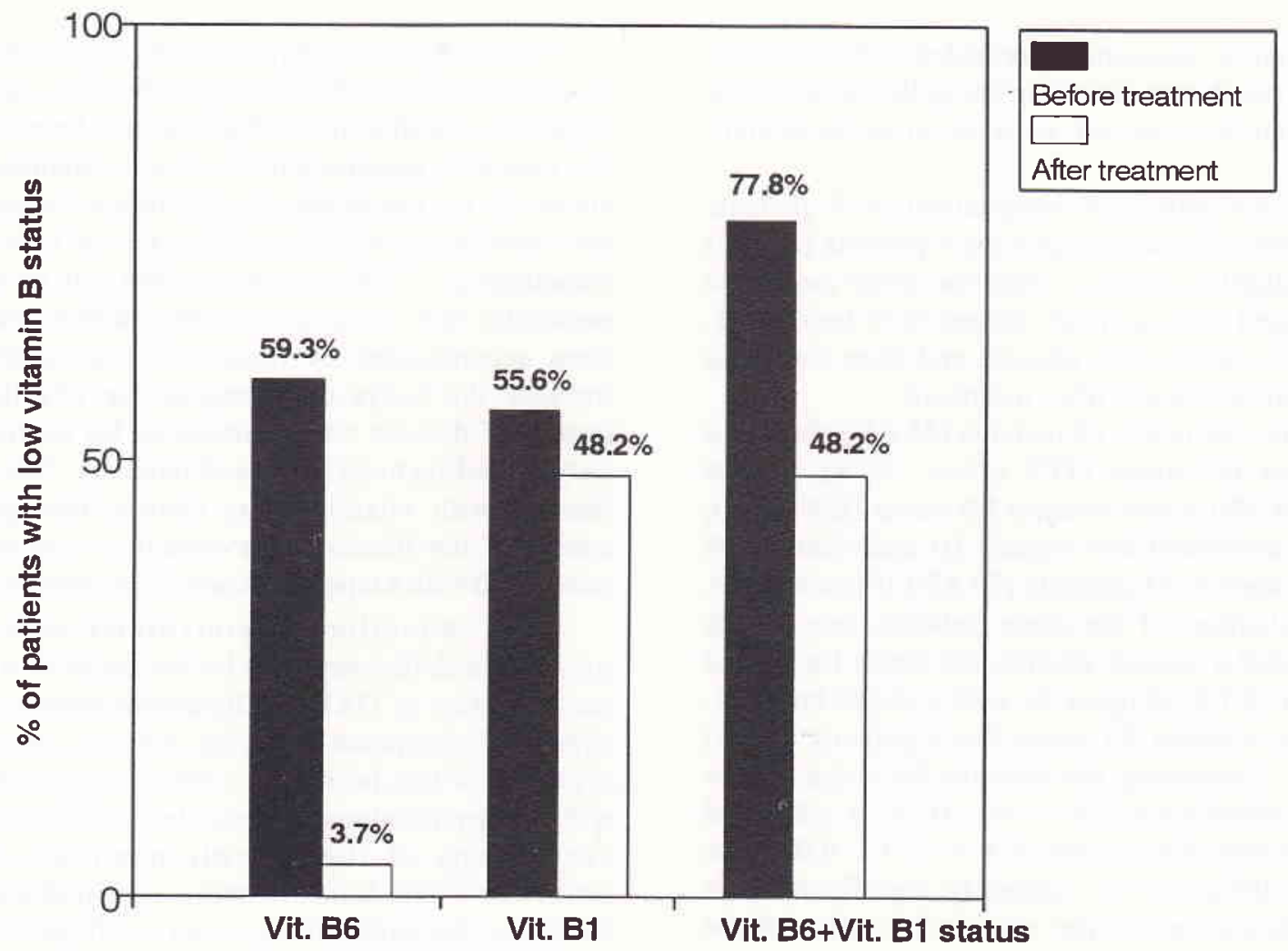

Figure 1. Histogram of the psychotic patients with low vit. B1, vit. B6 and a combined low vit. B1 and B6 status before and after treatment.



Figure 2. Vit B6 status of the psychotic patients on admintance and afier one month of hospitalization 


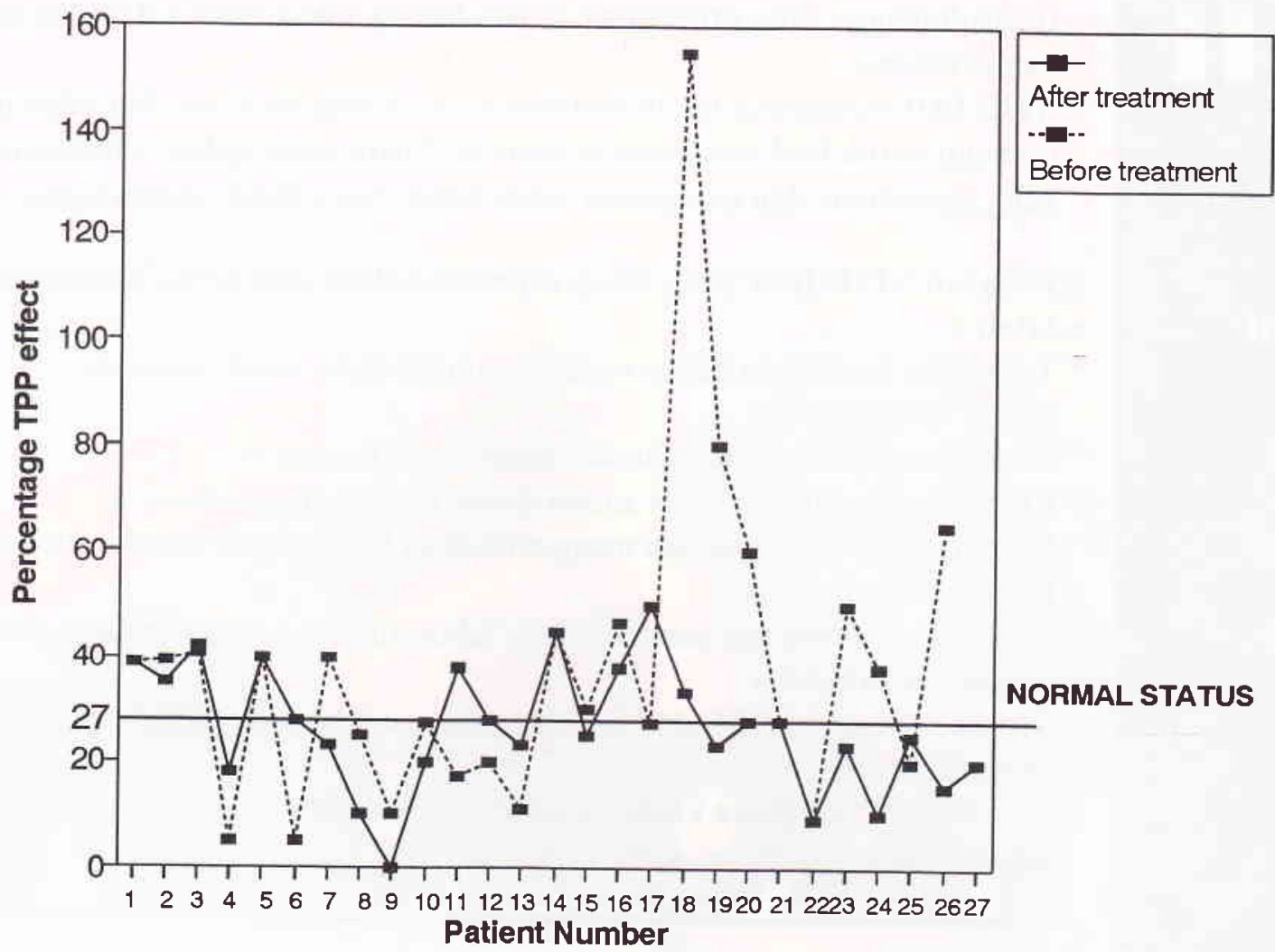

Figure 3. Vit B1 status of the psychotic patients on admittance and after one month of hospitalization

\section{REFERENCES}

1. Carlsson A. Early psychopharmacology and the rise in modern brain research. J Psychopharmacol 1990;4:120-6.

2. Cunningham TJ. Naturally occurring neuron death and its regulation by developing neural pathways. Int Rev Cytol 1982;74:163-86.

3. Hamburger V. Oppenheim RN. Naturally occurring neuronal death in vertebrates. Neurosci Comment 1982;1: 39-55.

4. Levi-Montalcini R. Developmental neurobiology and the natural history of nerve growth factor. Annu Rev Neurosci 1982;5:341-61.

5. Levi-Montalcini R. Angeletti PU. Nerve growth factor. Physiol Rev 1968;48:534-69.

6. Hyden H. RNA in brain cells. In: Quarton GC. Melnechuk T. Schmitt FO. editors. New York: Rockefeller Univ Press 1967;248-66.
7. Selak I. Skaper SD. Varon S. Pyruvate participation in the low molecular weight trophic activity for CNS neurons in glia-conditioned media. J Neurosci 1986;5:23-8.

8. Varon S. Skaper SD. Facci L. Rudge J. Manthorpe M. Trophic and metabolic couplings between astroglia and neurons. In: Althaus H. Seifert W. editors. Glial-Neuronal Communications in Development and Regeneration. New York: Springer 1986;491-504.

9. Setiadi E, Musram W, Hamopidjati D, Djalil H. Efek TPP (tiaminpirofosfat) dan konsumsi vit B1 sekelompok mahasiswa. Maj Kedok Indon 1991;41,645-8.

10. Musram W. Penetapan status vitamin B6 dengan uji aminotransferase eritrosit. Maj Kedok Indon 1994; 44, 154-7.

11. Roe DA. Drug interference with the assessment of nutritional status. Clin Lab Med 1981;1:647-64.

12. Dakshinamurti K. B vitamins and nervous system function. In: Wurtman RJ. Wurtman JJ. editors. Nutrition and the Brain. Vol I New York: Raven Press 1977;249-318. 